\title{
Autobiographical narratives of race and racism in Brazil: Critical Race Theory and language education
}

\section{Narrativas Autobiográficas de raça e racismo no Brasil: Teoria Racial Crítica em Estudos da Linguagem.}

\section{Aparecida de Jesus Ferreira* \\ $U E P G$}

\begin{abstract}
This research reflects the experiences of language teachers regarding race and racism in their lives in Brazil. The three main research objectives were to examine how these teachers personally encountered racism; what these teachers' narratives reveal about racism and the way that they reflect about their own racial identities; and finally, how the experiences of these teachers were transformed into action in their language classrooms and in their private lives. The theoretical framework used was based on Critical Race Theory (CRT), which was the basis for data analysis (LADSON-BILLINGS, 1998, LADSON-BILLINGS AND TATE, 1995). The methodology for data gathering was autobiographical narratives about these teachers' experiences of race and racism. The results showed that in one way or other these teachers faced issues of race and racism in their own homes, in schools as students, in university as students, as well as in their own working environments.
\end{abstract}

Keywords: autobiographical narratives, identity, race, Critical Race Theory, language education, Brazil.

Resumo: Esta pesquisa reflete as experiências dos professores de línguas sobre raça e racismo em suas vidas no Brasil. O objetivo principal da pesquisa foi examinar como as experiências desses professores foram transformados em ação em suas salas de aula de língua e em suas vidas privadas. O referencial teórico utilizado foi baseado na Teoria Racial Critica (Critical Race Theory - CRT) , que foi a base para a análise de dados (LADSON - BILLINGS, 1998, 1999, LADSON - BILLINGS E TATE , 1995). A metodologia de geração de dados foi narrativas autobiográficas sobre experiências de raça e racismo de professores de línguas. Os resultados mostraram que, de uma forma ou de outra estes professores enfrentaram questões de raça e racismo em suas próprias casas, nas escolas como estudantes, na universidade como estudantes, bem como em seus próprios ambientes de trabalho.

Palavras-chave: teoria racial crítica, estudos da linguagem, narrativas autobiográficas, Brasil, raça e racismo.

\footnotetext{
* Pós-doutora e doutora pela Universidade de Londres Inglaterra, professora Associada na UEPG no Programa de Pós-Graduação em Linguagem, Identidade e Subjetividade e professora do Programa de Doutorado em Letras na Unioeste Linguagem e Ensino. E-mail: aparecidadejesusferreira@gmail. com. Site: www. aparecidadejesusferreira.com
} 


\section{Introduction}

This research aims to reflect on the experiences of race and racism of language teachers in Brazil and seeks to understand how these particular teachers experienced race and racism in their lives. From 2011, I started collecting autobiographical narratives written by teachers as part of an MA course in language, identity and subjectivity that I teach at the Universidade Estadual de Ponta Grossa, Paraná, Brazil. These written, autobiographical narratives were produced as part of the activities of the course, in which I discuss professional identity and the social identities of race in the classroom. I collected 32 written autobiographical narratives of teachers from the field of languages (Portuguese, English as a foreign language, French as a foreign language, and Spanish as a foreign language).

Considering the significant impact that this activity had on the teachers who were attending the course I decided to analyse their written autobiographical narratives. Other research Ladson-Billings (1998); Moita Lopes (2002); Milner (2010); Ferreira (2012, 2015a, 2015b); Pessoa (2014) has shown that it is difficult for teachers to address the issues of race and racism in the classroom if they are not adequately prepared Consequently, this research was designed to examine the teachers' specific experiences of race and racism.

Research conducted by Ferreira in Brazil (2004, 2009, 2012a), which observed classroom interactions between students-students and teachers-students, concluded that the voices of the students should be heard more, and that they should be more involved in the process of teaching and working towards actions that can challenge race inequality in education. The data collected from students and teachers by race/colour/ethnicity clearly demonstrated that the experiences of racism that were mentioned by the participants merited further reflection and prompted consideration about potential actions to challenge racist behaviour. This is an aspect that needs to be discussed with students and teachers in a way that helps them to reflect on their own identity. This research attempts to understand how teachers have experienced race and racism in their lives and these experiences are reflected in their autobiographical narratives.

Changes to the Brazilian curriculum in relation to the issues of race took place in January 2003, with the instigation of Federal Law 10.639/2003, which made the teaching of African and Afro-Brazilian history and culture mandatory (BRASIL, 2005). According to Brasil (2005), African, and Afro-Brazilian history and culture should be taught within all subjects of the school curriculum. The contribution of this legislation to education in Brazil was welcome in terms of addressing issues that were previously absent in curricula and in teacher education courses. 
All schools, universities and teachers in Brazil should now be prepared, through their teaching development courses and continuing education, to include questions that address the issues of race and ethnicity in the curriculum. However, in reality this depends on the individual school or university, and compliance with this legal requirement is not currently being monitored. The government guidelines for the teaching of African and Afro-Brazilian history and culture provide guidance on what content to teach, and the guidelines are also intended to raise general awareness that racism exists in Brazil. It is intended that teaching about Afro-Brazilian culture will be achieved by well-developed teaching material as well as teachers who are prepared to deal with the issue in the classroom (MOITA LOPES, 2002; BRASIL, 2005, FERREIRA, 2006 2008, 2011; JORGE, 2012).

The inclusion of this content in the curriculum was urgently needed, given the previous lack of representation of topics that address issues of race and ethnicity in the curriculum. However, one element of concern with regard to Federal Law No. 10.639/2003 was the lack of preparation of teachers to implement the discussion of race and ethnicity in the school context, which was one of the main motivating factors for the present research.

Thus, the issues to be addressed in this article are: how these teachers personally encountered racism; what these teachers' narratives reveal about racism and the way that they have been able to reflect on their own racial identities; and finally, how these teachers' experiences were transformed into actions in their language classrooms and in their private lives.

This article starts with a brief discussion of the issue of race in Brazil. This is followed by some reflections on the use of autobiographical narratives, critical race theory (CRT) and language education. The methodology of the data gathering is then outlined. The analysis is separated into three sections: reflections on teachers encountering examples; the impact on their racial identities; and how their experiences were turned into actions in their teaching and in their private lives.

\section{Race in Brazil}

According to the IBGE, the official classifications of colour, race and ethnicity in Brazil are: Branco (white - European descendants), Preto (black - Afro-descendants), Pardo (mixed race of Black and White), Indígena (native Brazilian Indian - Brazilian native Indian descendants) and Amarelo (Yellow - Asian descendants). According to the 2010 census, the population of Brazil was 190,749,191. The population was divided as follows: Black, 14,517,961 (7.61\%), mixed race (Pardo) 82,277,333 (43.13\%), White 91,051,646 (47.73\%), native Brazilian Indian 817,963 
(0.42\%), Yellow (Asian descendants) 2,084,288 (1.09\%). If the Black and mixed race (Pardo), which are the Afro-descendant/Afro-Brazilian segments of the population, are added together this represents $50.74 \%$ of the Brazilian population. Researchers in the field of race tend to combine the categories of Black (Pretos) and mixed race (Pardos) because when research is carried out regarding schooling, employment, medical access and housing, there is no significant difference for Black and mixed race people in the results. In Brazil, Black people tend to self-identify themselves by referring to colours such as moreno (brown), moreno claro (light brown), moreninho (little brown) etc (see FERREIRA, 2011). As my data was gathered in the university environment I will mention some statistics about the racial profile of people who have taken post-graduate courses in Brazil; the information is provided by Paixão (2010, p. 242). The numbers that follow are by race/colour: White (year 1988, 44,097; year 1998, 160,584; year 2008, 258,738), Black and mixed race (year 1988, 3,517; year 1998, 25,255; year 2008, 65,045). This data clearly shows which racial groups have had access to post-graduate university education. As I have written elsewhere:

Regarding racial terminology, Afro-Brazilian activists used to prefer to use the term 'Negro' relating to a Black person. They preferred this term because it is associated with ethnic origin rather than colour. Recently, black activists introduced the terms 'Afro-descendant' and 'Afro-Brazilian' as a way to self-define. However, people who are not aware of this still use the terms 'Preto' (Black) and 'Negro' interchangeably. (FERREIRA, 2011, p. 22)

I choose to use the word 'race' in this article to refer to a socially constructed phenomenon (Ladson-Billings, 1998).

\section{Autobiographical narratives and Critical Race Theory in language teacher education}

Over the last few years a lot has been done in the field of narrative research in education (CLANDININ; CONNELLY, 1998, 2000); in language education and teaching English to speakers of other languages (TESOL) (BELL, 2002; BENSON \& NUNAN, 2005; PAVLENKO, 2007; TSUI, 2007; KAJALA, MENEZES \& BARCELOS 2008; FERREIRA; 2009; ROMERO, 2010; NORTON AND EARLY, 2011; BARKHUIZEN, 2011); and in the field of race that considers the importance of narratives (LADSON-BILLINGS, 1998; BELL, 2003; FERREIRA, 2004, 2009; MILNER, 2010; LACHUK \& MOSLEY, 2012; DIAS, 2013;). According to Clandinin \& Connely (2000), '[...] life - as we come to it and it comes to others - is filled with narrative fragments, enacted in storied moments of time and space, and reflected upon and understood in terms of narrative unities and discontinuities' (CLANDININ \& CONNELLY, 2000, 17). 
In this research I adopt the framework of CRT, which is important in terms of my research because it has been used in the field of education to address issues of race and racism. Although CRT started in the legal field (DELGADO \& STEFANCIC, 2000, xvi), Ladson-Billings \& Tate (1995) are acknowledged for introducing CRT into the field of education. In this article, I am interested in the aspect of CRT that is related to stories, narratives and counterstories. Ladson-Billings (1998) claims that:

The use of voice or "naming your reality" is a way that CRT links form and substance in scholarship. CRT scholars use parables, chronicles, stories, counterstories, poetry, fiction, and revisionist histories to illustrate the false necessity and irony of much of current civil rights doctrine. (LADSONBILLINGS, 1998, p. 13)

Milner and Howard also contribute to this discussion by claiming that "[...] narrative and counter-narrative should be captured by the researcher, experienced by the research participants, and told by people of color. [...] race and racism are placed at the center of analysis through the narrative and counter-narrative in CRT.” (MILNER \& HOWARD, 2013, p. 542)

Since the introduction of the CRT approach to education by LadsonBillings and Tate almost twenty years ago (1995, see also Ladson-Billings, 1998), many researchers have been using this approach within educational research as a theoretical and analytical framework (BELL, 2003; PARKER \& STOVALL, 2004; GILLBORN, 2009; MARX AND PENNINGTON, 2003; MILNER, 2010; MILNER \& HOWARD, 2013; and many others). The theoretical framework of CRT has also been used in the fields of TESOL and language education (FERREIRA, 2004, 2007, 2009, 2011; 2014; MICHAEL-LUNA, 2009; KUBOTA \& LIN, 2009; SANTOS, 2011; DIAS, 2013; LIGGETT, 2014; KUBOTA, 2015)

After finishing my PhD in 2004 (FERREIRA, 2004), in which I used the tenets of CRT to analyse my research data, I went back to teaching and I gradually introduced autobiographical narratives as part of the themes to be discussed in the MA course that I teach at UEPG. There is a moment in the course when we discuss professional identities and there is another moment when we discuss racial identities and their impact in language teaching. Firstly, we discuss some theoretical issues concerning race and racism and I ask the teachers to write, in their own homes, an autobiographical narrative answering the question "How did you first become aware that racism exists?” There is a later moment in the course when all the teachers share their autobiographical narratives of experiences of race and racism in their lives, and this normally triggers an explosion of emotions from most of the participants. When I did this for the first time I was very surprised to see that many teachers were moved to tears. Now, after having done this 
for several years, I am more aware of what is likely to happen and I am more prepared to deal with the reactions of the teachers. At the end of the course I always do an evaluation with the participants and for most of them the high point of the course is the sharing of personal experiences. It is clear that this discussion about race and racism can have a positive impact on teachers' ways of viewing the issue. Similar experiences have occurred in research carried out by Milner (2010): “Indeed, the sharing of racerelated narratives can prove meaningful and productive in helping students and teachers understand, think about, and change their thinking about such issues. Once students (and teacher educators) know better, they are more likely to do better.” (MILNER, 2010, p. 199, his emphasis).

As this article is related to race and racism in the field of language education, foreign language education, TESOL and applied linguistics, it is important to point out that significant research has been done in the field over the last few years in Brazil, such as Moita Lopes (2002); Ferreira (2006, 2007, 2008, 2011, 2012a; 2012b); Silva (2009); Azevedo (2010); Ferreira and Ferreira (2011); Santos (2011); Jorge (2012); Barros (2013); Ferreira \& Camargo (2014); Pessoa (2014) and in many other countries such as Van Dijk (1993); Ibrahim (1999); Motha (2006); Ajayi (2011); Kubota and Lin (2006, 2009); Ligget (2009, 2014); Luke (2009); Ruecker (2011); Mitchell (2013); and Kubota (2002, 2015);

\section{Methodology}

This article is based on qualitative research (DENZIN \& LINCOLN, 2000). The autobiographical narratives were generated during an MA course (Language Teacher Education) that I teach at the Universidade Estadual de Ponta Grossa. The course lasts 60 hours over one semester. The data was generated during 2011, 2012 and 2013. The theoretical framework used to generate data were authors who research about autobiographies and narratives, and working with reflections on teacher education and language teacher education (CLANDININ \& CONNELLY, 1998, 2000; BELL, 2003; BAMBERG, 2006; PAVLENKO, 2007; MILNER, 2010; Norton \& Early, 2011). The autobiographical narratives of these teachers intersect experiences linked with race and racism, which are lived in the classroom, in the home environment, and in the social environment. For this research the following autobiographies were generated. 
Table 1: Race, colour and gender of the 32 teachers who provided autobiographical narratives

\begin{tabular}{l|r|r|r|r}
\hline Year & 2011 & 2012 & 2013 & Total \\
\hline Black female & 1 & - & 2 & 3 \\
\hline Black male & - & - & - & - \\
\hline Mixed race female & 2 & 4 & 3 & 9 \\
\hline Mixed race male & - & - & - & - \\
\hline White female & 7 & 1 & 10 & 18 \\
\hline White male & - & 2 & - & 2 \\
\hline Total & 10 & 7 & 15 & 32 \\
\hline
\end{tabular}

Table 2: Languages taught by teachers

\begin{tabular}{l|r|r|r|r}
\hline Year & 2011 & 2012 & 2013 & Total \\
\hline Portuguese & 4 & 2 & - & 6 \\
\hline English as a foreign language & 4 & 3 & 10 & 17 \\
\hline Spanish as a foreign language & 1 & 1 & 4 & 6 \\
\hline French as a foreign language & 1 & 1 & 1 & 3 \\
\hline Total & & & & 32 \\
\hline
\end{tabular}

The autobiographical narratives that I refer to in this article are important in order to understand the need for the preparation of language teachers to work with issues of race and racism, not only in the classroom but also in the whole school environment and in their own lives. There have been several examples of research conducted in different countries about narratives in the field of education (CLANDININ \& CONNELLY, 1998, 2000) and in applied linguistics (VAN DIJK, 1993; TELLES, 2002; PAVLENKO, 2007; KAJALA, MENEZES \& BARCELOS, 2008; FERREIRA, 2009; NORTON \& EARLY, 2011; BARKHUIZEN, 2011; BARKHUIZEN, BENSON \& CHIK, 2014), which demonstrate the importance of narrative research and autobiographical narrative research.

As explained in the previous section, I will use Critical Race Theory (CRT) as a framework to analyse the autobiographical narratives of the teachers. In the process of my analysis I worked with the data in different phases. In the first phase I read the 32 teachers' autobiographical narratives and I coded them following what Corbin \& Strauss (1990) have to say about themes and the coding of data. In the second phase, I re-read the autobiographies and separated them into themes so that I could answer the research questions, and in the third phase I analysed them. Due to ethical considerations I will be using codes to identify each teacher and the codes are as follows: T1 (teacher 1), BF (black female), MRF (mixed race female), WF (white female), WM (white male), PT (Portuguese teacher), 
EFLT (English as a foreign language teacher), SFLT (Spanish as a foreign language teacher) and FFLT (French as a foreign language teacher).

\section{Language teachers encountering about race and racism: counterstories}

Counter-storytelling is a means of exposing and critiquing normalized dialogues that perpetuate racial stereotypes. The use of counterstories allows for the challenging of privileged discourses, the discourses of the majority, therefore, serving as a means for giving voice to marginalized groups. (DECUIR \& DIXSON, 2004, p. 27)

This section discusses how the language teachers who participated in this research first encountered racism in their own lives. Some of them discovered about racism in their own home, or in school as a child, as we can see below:

I was introduced to racism at home. [...] My grandfather was black, but my mother denies her own origins. I say this because of the way she vehemently asserts that blacks are worthless; they just cause problems and do bad things. She also used a series of [racial] expletives that I heard throughout my life. (T9, WF, PT)

Well, as I'm a black woman, it wasn't very difficult for me to be aware of the existence of racism. Since I started going to school, even in pre-school, I was already aware that no classmates approached me. Besides being black, I was poor. My mother was very sick, but she always worked to keep the house, she always worked extra hours to increase the family income. She always kept us in school. In order for me to go to nursery school I had to spend the week at the home of an aunt who lived near that particular school. I never had a very close relationship with my mother because she was always working and when she was at home she did sewing jobs for people. She had no time for long conversations; she was very affectionate but she didn't have enough time to discuss issues such as racism. However, she was always very present in the school, I mean when she was asked to attend meetings. (T10, BF, SFLT)

Racism was the conflict that I was talking about. I encountered it as soon as I left my mother's womb. When my father saw me for the first time in the maternity hospital he told my mother that he disowned me from that moment because she was not able to have a white daughter, since all my siblings (three) were born black, like our father [...] From then on I started to notice all the overt and all the subtle racist attitudes. Being a black man or woman enables you recognise racism and prejudice, often simply through looks. (T30, BF, FFLT) 
The narratives of Teachers 9, 10 and 30 shows a common pattern about experiencing racism in their own homes and also some experiences of black teachers, whose own black relatives made negative comments about race. Brasil (2005, p.16) argues that it is incorrect to state that black people are racist against their own race and that this should be understood instead as the result of a whitening ideology that emphasises the social privileges of being white. Brasil (2005) goes on to assert that:

It is worth remembering that in the post-abolition period policies were formulated aimed to whiten the population by eliminating the symbolic and material presence of black people. Thus, it is possible that black people may be influenced by the ideology of whitening and they may tend to reproduce the prejudices of which they are victims. Racism leaves a negative influence on the subjectivity of black people and also on those who discriminate against them. (BRASIL, 2005, p. 16)

The ideology of whitening that Brasil (2005) refers to above, also has an impact on the identity of white people, who continue to say things and take actions that put black people in less privileged positions, as shown in the narratives by Teachers 1,13 and 16 that follow:

I can't really tell you when I first became aware of the existence of racism: I just know that I repeated songs, rhymes and sayings that they taught me when I was a kid, like “don't go upstairs or the black bogeyman will get you”. (T1, WF, FFLT)

From childhood, I always heard and saw discrimination as regards race, either in jokes and/or anecdotes where the "guilty" person was almost always black [...] In my municipal elementary school, I remember an incident involving two students. They were siblings, a boy and a girl, both black, from a dysfunctional family situation and working class. Those were the two reasons why they were ridiculed by some classmates because (the two factors were not necessarily related). They had already had to repeat the year and they lived in an underprivileged part of the city. I remember that even though we were children aged about seven, racial segregation was already within the classroom; there was a distancing between "us whites" and them. (T13, WM, FFLT)

I think that I had already realised that there was prejudice in my family as a child, even without knowing what to call it. When my grandfather, who was of German descent and who was very strict, instructed us to do something he would add “and I don't want done in a black [sub-standard] way" [...] So I think I started to realise that prejudice existed and that it was something significant. These types of issues (all kinds of prejudice) are now being addressed more openly in the media and it made me see a different reality to that which I had experienced. (T16, BF, EFLT) 
The preceding narratives show the voices of people who were taught as children that being black meant being ugly, that black people should be feared, that black people could be joked about, called names, belittled, made to feel guilty about things that they didn't do, and told that what they did was not correct or not good enough. These narratives clearly show the privilege of being white in Brazilian society and are evidence of attitudes of white supremacy (GILLBORN, 2009); they also show who has the power to have their voices heard in Brazil. Similar experiences can be found in studies by Bell (2003); Ferreira (2009); Milner (2010). In the following narratives, teachers 31, 12 and 4 talk about the issue of whiteness as a property (LEONARDO, 2002; DECUIR AND DIXSON, 2004;) and also about the experience of living in a colour-blind society (FERREIRA, 2011; LADSON-BILLINGS, 1998). The narratives of Teachers 31 and 12 that follow, show the privilege of being white:

I was always described as being blonde with blue eyes when I was growing up. I never noticed the importance and relevance of discussing issues related to racism. I confess that I didn't even think about this subject because I was living in a comfort zone; the stereotypes that come to mind when you think about someone with the physical characteristics I have described above are largely positive. [...] Reflecting about how I first realised that racism exists, I think that it came about through the media; I saw news about prejudice and racism, [...]. Another point to consider is that the opinions of parents are ultimately the benchmark for children. I think that even seeing situations of prejudice and racism this could mean that some people would think that they were acceptable, perhaps going along with the views of their own family. (T31, WF, EFLT)

[...] It's difficult to admit that, in some ways, we live in a country that is dominated by the idea that Brazil is a white society. I thought that this problem had already been completely resolved. However, I notice that there are still some traces of racist attitudes. I always realised that racism existed, but it is very polemical to discuss the issue. In all social spaces there is always someone saying that whenever something is done wrongly, it is because it was a black person was responsible. Also people often use expressions that are connected to racial segregation. (T120, WM, EFLT)

When I started doing teacher training and working with students in the classroom, I began to really realise that there is still racism in our country even though many people tend to say that there is no colour prejudice in our society. I realised that many children were discriminated against because of their colour. (T4, MRF, EFLT)

These narratives show that, for those who have the privilege of being white, things are seen from a different perspective. Bell's comment below (2003) echoes the experiences of some of the narratives discussed in this section. 
When white respondents told stories about what they learned from their parents, or about what they as parents teach their children, very few articulated stories of overt training in racism. More often they described a complicated blend of mixed messages, evasions and distortions that nevertheless communicate a coherent ideology of color-blindness. (BELL, 2003, p.15)

\section{Reflections on the racial identity of language teachers}

When we look at the role of storytelling in both CRT and TESOL, the notion of identity is not a fixed essence, but rather an assemblage of positions, narratives, and discourses constructed from relationships, experiences, and individual positionality. (LIGGET, 2014, p. 118)

In this section I discuss the teachers' narratives, which had an impact, in one way or another, on their perceptions about their own racial identity. The narrative of Teacher 25 that follows, shows that for this particular black teacher, even though she was more qualified than the other person who was being interviewed for the job, it was clear that the choice of who was eventually offered the job was based on race, and whiteness as a property. The discourse of whiteness is explicit in the narrative of Teacher 25. Decuir \& Dixson (2004) argue that whiteness is one of the tenets of CRT that can be used in the field of education.

Once, I went to a job interview and there was another [white] girl there. I clearly felt the difference in treatment between us. I was much more qualified for the vacancy; however I was not selected. I felt during the conversation with the interviewer that there was no way that they were not going to offer me the job. (T25, BF, EFLT)

This experience had a big impact on the identity of Teacher 25 as a future teacher, on her own self esteem, and in relation to her potential access to all sorts of capital (economic, cultural, and social) that she would have had if she had been given the job that she applied for. What is important here, is allowing her to make her voice heard in relation to this experience. According to Dixson \& Rouseau, "We should make clear, however, that the use of the term 'voice' in the singular does not imply the belief that there exists a single common voice for all persons of colour. The stories of individuals will differ”. (DIXSON \& ROUSSEAU, 2005, p. 11). The narrative of Teacher 30 that follows shows how she encountered racism in her own home.

When I was very small, for several months, my father was always looking at the tips of my fingers to see if they would get any darker, while my mother, without him knowing, tied my nose with a clothespin or squeezed 
my nose three times in the morning and three times before I went to sleep, to make it thinner. She justifies this, even to this day, by saying that she did this to all my brothers and that at that time all mothers did this to their children, for their own good, because having a flat or a wide nose meant being teased for life and made it hard to date or get married. She also said that a flat or wide nose was not pretty. (T30, BF, FFLT)

It is clear from the narrative of Teacher 30 that her own identity was heavily influenced by a standard of beauty which upheld whiteness as the ideal. The two narratives that follow from Teachers 17 and 29 discuss the discourse of colour-blindness experienced by white teachers:

Having lived in a family surrounded by racism, for a long time I thought that it was all very natural and normal. Individuals are socially and historically constructed and I've always been surrounded by information that told me that black people are inferior. [...] Because I don’t have black skin myself I have never personally suffered from any form of racism, so it's very easy to ignore the issue when it doesn’t affect you directly. (T17, WF, PT)

My father was a racist, to such an extent that his behaviour was sometimes ridiculous. He often had to deal with something important, some business, signing a document etc. If he met a black person as he was leaving home, especially if it was a black woman, he would come home and say a prayer before going out again. In his twisted mind he believed that this was a harbinger of something negative, he associated the colour of the person with negativity. For a long time, especially in my childhood, I also thought that his view of black people, and his prejudice, was normal, because of years of living in contact with those views. (T29, WF, EFLT)

The narratives above are important because they enable us to understand how being overtly racist can be seen as "normal"; these teachers clearly did not have access to counter-narratives in their own homes. The experiences recounted by these teachers happened to them when they were children, or as adults, but they still remember them vividly. Their experiences seem to echo similar experiences mentioned in research by Bell (2003):

Another interesting characteristic of the counter-narrative stories was their timelessness. Some stories were clearly recent, while others recalled experiences from years ago. These stories about long ago incidents were frequently told not as past history that is over and finished, but as encapsulating lived experience up to and through the present time. Respondents offered such stories as emblematic tales that bridge past and present to illustrate the continuities of racism in contemporary daily life. (BELL, 2003, p. 9)

The counter-narratives highlighted in this section show that race and racism is very present in the experiences of Black and White teachers. 


\section{Reflections on the roles of teachers both in teaching and as researchers in the field of language education}

[...] issues of race address power, identity, subjectivity, and social (in) justice, which are vital to all aspects of second language education. (KUBOTA \& LIN, 2009, p. 1)

Teacher 26 was a pedagogical coordinator in a school and in charge of teachers when she had the following experience:

I heard a commotion coming from one of the rooms on the second floor and then some students appeared who were quite upset. They asked me to go up because something awful was happening in their class room. When I arrived, I ran into an astonishing scene: one of the students was quarrelling with a Biology teacher, who was black, and she [the teacher] was visibly upset. She was crying and yelling at some boys who were not intimidated by her in the slightest. One of them was abusing her all the time and some of the others were joining in. Some of the students tried to calm the teacher and others booed, whistled and joined in the argument. Keila, the teacher could not speak because she was so nervous. I asked her to go away with another teacher, who had possibly heard what had happened and I stayed with the class to try and find out what had happened. The students explained to me that for a long time some of their fellow students had been tormenting the teacher because of her colour, but she went along with the joke and she never complained about it. But on that particular day, while the teacher was talking about evolution, one of the boys started saying that the teacher had not evolved and that she was still a "monkey". The teacher could not control herself and she started hitting the student. I did not know what to do. I never imagined that in this day and age racial abuse like this could still happen. I called an inspector to supervise the students and I went downstairs to talk to the teacher. She said that she should not have let things get to that point, she should have put an end to those jokes that were in bad taste, and she should have advised the school directors. It was then that I got another shock: the teacher had already discussed the ongoing problem with the school coordinator, before speaking to me, and the coordinator had made similar bad taste jokes. Consequently, she had decided to keep quiet and to deal with the problem alone because she was a substitute teacher and she really needed that job. I immediately called the families of the students involved and encouraged her to make a police report. (T26, WF, EFLT)

Teacher 26 recounts an experience of explicit racism that happened to her colleague. This disturbing experience shows that is it extremely important that teachers are educated to know how to deal with situations like that faced by her colleague. In relation to the example given by teacher 26 Liggett (2014) claims that " [...] the historical context that frames discourse around English language education, and how this context overlaps with 
race, racial identity, and racialisation” (LIGGETT, 2014, 122). Although the experience mentioned by Teacher 26, who is a teacher of English as a foreign language, did not take place in her own classroom, nevertheless, she had to resolve the situation. The experiences of narratives of Teachers 18 and 27 that follow seem to confirm what Teacher 26 mentions. Racism is endemic and it is everywhere, which is one of the main tenets of CRT (LADSON-BILLINGS, 1998):

I have noticed that early in the school year, when there is an Afro-descendant student in the class, it usually takes a little longer for them to make friends. This year, I have a student who took almost the whole of the first term before he started playing with other students during breaks and during class he hardly spoke, and only when he was directly asked to participate. So I started making the students work in groups and I noticed that he started to talk more and to play with other students in the playground. (T18, WF, EFLT)

By paying more attention to the kind of conversation that occurs between teachers in meetings, in moments of relaxation, such as recess and breaks, and even in class councils, the sad reality of their mockery and intolerance of colleagues and students can be seen [...] For example, I had not stopped to think that the silence of teachers in the classroom in the face of students using nicknames, making jokes in bad taste etc. can reinforce prejudices, and that the attitude of teachers in the face of such conflicts should be cautious and conciliatory without reinforcing stereotypes or prejudices. These are questions that make all the difference in the classroom and subsequently they will make a difference in society. (T27, WF, EFLT)

These narratives from Teachers 18 and 27 refer to their experiences with the issues of race inside their classes, which are experiences that intersect language education and racism. This demonstrates that language teachers need to be prepared to deal with issues of race in the school environment and where they work. Pennycook (2001) is an applied linguist and he considers that language is political and that it is embodied with power "in relation to questions of class, race, gender, ethnicity, sexuality, and so on [...]" (PENNYCOOK, 2001, p. 135). Pennycook's comment shows that once teachers are prepared and aware that teaching a language is connected with relating that language to issues of power that also intersect with race, then those teachers can have different views about the role of teaching a language and also conducting researching about that language. This is shown in the narratives from Teachers 11, 22, 6 and 25 that follow:

Through reading and discussions I am now able to perceive issues of prejudice and racism, through language, gestures and even through silences. I realise that racism is present everywhere, between men and women, blacks and whites, between social classes, in the media (TV soap operas, cartoons), in jokes, nicknames, etc. (T11, WF, SFLT) 
Following my studies, I had the great pleasure of doing a course within my MA that addressed the issue of racism. This prompted me to work with this issue in school, in the classrooms, towards a just and necessary equality among students. The course gave us directions to give voices to prejudiced students, to empower them to defend their rights and to be aware of their importance in the world as citizens. (T22, MRF, SFLT)

The main reason why I decided to carry out research on the issue of race was the fact that I worked with students who were of German descent and I noticed how Eurocentric culture is strong in the city where I live. I also realised that we need to rethink our concepts of culture and society. [...] My childhood friends still think that marrying a black person is out of the question. I still hear students saying that blacks are worse workers than whites. At home I still hear derogatory remarks about blacks and about women. Through discussions in my MA course, as well as readings and research on the topic, my outlook changed a lot. It is fundamental to understand how we are conditioned to be racist from an early age and it is crucial to learn to deal with the situations involving racism that we experience on a daily basis [...]. When I see racist behaviour I feel as offended as a black person, in the same way that I feel offended when I see prejudice against women, the poor, etc. It is increasingly difficult to live in this society and it's getting worse. (T6, WF, EFLT)

After having done my teacher training course I feel more aware and able to defend my point of view. (T25, BF, EFLT)

Pennycook (2010) observes that '[...] when we look at language as a local practice [...], we can start to see how locality is about much more than merely being in a location; rather, it is about the becoming of place' (PENNYCOOK, 2010, p. 14). This seems to be reflected in the narratives of Teachers 11, 22, 6 and 25 above, who understand that their role of teaching a language and researching the issue of race in the field of language and applied linguistics changed after they were able to reflect about racism in their social practices; this changed their way of seeing the interrelationship between language education and the possibilities of researching in the field of social identities of race. I agree with Pennycook (2010) when he claims that:

Local landscape are not blank canvases or spatial contexts but integrative and invented environments. The importance of movement, of interactive spaces, leads us into an understanding of locality as a dynamic place. (PENNYCOOK, 2010, p. 14)

Consequently, whether the language that is taught in Brazil is Portuguese, English as a foreign language, Spanish as a foreign language or French as a foreign language, as was the case with the teachers who participated in this research, their experiences with race and racism shows 
that these themes are issues for the "local practice" to address. These issues need to be addressed within the context of teacher education courses. This is of fundamental importance because when teachers face the experiences outlined in the narratives above in their local practices they will be better prepared to understand the interrelationship between language education and race and have a strategy to address that issue.

\section{Race and racism in language teachers' private lives}

"While stories about race and racism may derive from individual experiences, they also communicate cultural assumptions and habits of thinking that transcend the individual” (BELL, 2003, p. 4)

The extract below is from a long narrative, in which the teacher starts by saying that her (white) daughter verbally offended a black neighbour's child several times when the two children were playing together. Teacher 8 explains what then happened:

I took my daughter home and tried to show her how much she had hurt the other girl, who up until then had been her friend. I was pregnant with my second child. I reminded her that her grandfather was black and that her favourite aunt was the same colour as the little girl that she had offended. I reminded her that my baby that would be born soon might be the same colour and that she would not like to see her future brother or sister to be humiliated. She listened to me very seriously and promised that he would not do it anymore and that she would apologise to her classmate. The next day they were both playing happily together again. (T8, WF, PT)

I don't want my children to hear their grandfather or any other black person being called a "monkey". Respect and tolerance must be the basis of human development. (T15, WF, EFLT)

These narrative from Teachers 8 and 15, clearly demonstrate that experiences of race and racism go far beyond the classroom. However, the school environment is one of the places where teachers and educators can address those issues and provide alternatives that are more directed towards social justice.

\section{Final considerations}

I will now answer the research questions I posed at the start of this article. As the narratives show, these teachers found out about the existence of racism in their homes, with their family, in their schools as students, and in their schools as teachers. 
The narratives demonstrate that it was the various experiences that the teachers had in their homes, schools, and the contact that they had with race and racism, that made them reflect on the own racial identities. These experiences changed the way that they see black and white people and it took them time to reflect and reconstruct the way that they thought about racial identity. The way that they viewed racial identity was constructed for them and not by them. The experiences of both black and white teachers that they shared with each other during the course allowed them to learn with each other about the painful experiences that racism can provoke. It took them time to deconstruct the views about black people that had been constructed for them.

From these narratives it seems that if language teachers are allowed the time and the opportunity to reflect on these issues then they can make changes in their classroom environment and also in their private lives. This research shows that using autobiographical narratives in research related to race and racism can bring about such reflection and that it can also prepare language teachers to understand how to use Federal Law 10.639 in a way that can consider the needs and aspirations of students of all races within the school environment.

\section{Acknowledgements}

I would like to thank all the teachers who took my MA course at the Universidade Estadual de Ponta Grossa (UEPG) and who generously shared their experiences with me and the group of teachers. I also would like to thank CAPES - Grant - BEX 10758/13-5, this research was funded by a scholarship from the Coordination of Improvement of Higher Education Personnel (CAPES), Ministry of Education, Brasília, DF, Brazil, whose funding has been crucial to my Visiting Research Fellow at King's College, University of London (February, 2014 to January, 2015). Finally, I would like to thank my department at UEPG (DELIN) and Universidade Estadual de Ponta Grossa, Paraná, Brazil for supporting my leave of absence.

\section{References}

Ajayi, L. (2011). Exploring how ESL teachers relate their ethnic and social backgrounds to practice. Race Ethnicity and Education 14 (2), 253-275.

Bamberg, M. (2006) Stories: Big or small: Why do we care? Narrative inquiry, v. 16, n. 1, p. 139-147.

Barkhuizen, G. (2011). Narrative knowledging in TESOL. Tesol Quarterly 45 (3), 391-414. 
Barkhuizen, G (2013). Narrative research in Applied Linguistics. Cambridge: Cambridge University Press.

Barkhuizen, G; Benson, P.; Chik, A. (2014). Narrative inquiry in language teaching and learning research. London: Routledge.

Barros, J. S. (2013). Identidades sociais de classe, gênero e raça/etnia representadas no livro didático de espanhol como língua estrangeira. Brasília, MA dissertation. Programa de Mestrado em Linguística Aplicada, Universidade de Brasília, DF.

Bell, J. S. (2002). Narrative research in TESOL: Narrative inquiry: More than just telling stories. TESOL quarterly 36 (2), 207-213.

Bell, L. A. (2003). Telling tales: what stories can teach us about racism. Race Ethnicity and Education, 6 (1), 3-28.

Benson, P., \& Nunan. D. (2005) Learners'stories: Difference and diversity in language learning. Cambridge: Cambridge University Press.

Brasil. (2005). Diretrizes Curriculares Nacionais para a Educação das Relações Étnico- Raciais e para A Educação das Relações Étnico-Raciais e para o Ensino de História e Cultura Afro-Brasileira e Africana. Brasília: Secretaria Especial de política de Promoção de Igualdade Racial, MEC Ministério da Educação.

Clandinin, J. D., \& Connelly, M. F. (2000). Narrative Inquiry: Experience and story in qualitative research. San Francisco: Jossey-Bass.

Clandinin, J. D., \& Connelly, M. F. (1998). Personal experience methods. In: N. Denzin \& Y. Lincoln (Eds.) Collecting and interpreting qualitative materials, (pp.150-158). London: Sage Publications.

Corbin, J. M., \& Strauss, A. 1990. Grounded theory research: Procedures, canons, and evaluative criteria. Qualitative Sociology, 13 (1), 3-21.

Decuir, J. T., \& Dixson, A. D. 'So When It Comes Out, They Aren't That Surprised That It Is There”: Using Critical Race Theory as a Tool of Analysis of Race and Racism in Education”. Educational Researcher, 33 (5), 26-31.

Delgado, R, \& Stefancic. J. (2000). Introduction. In R. Delgado, \& J. Stefancic (Eds.) Critical Race Theory: The Cutting Edge, (pp. xv-xix). Philadelphia: Temple University Press.

Denzin, N. K., \& Lincoln, Y. S. (2000). Handbook of qualitative research. Thousand Oaks, California; London: Sage.

Dias, R. S. (2013). Desafios enfrentados por alunos de classes sociais menos favorecidas rumo à aprendizagem de inglês: uma questão de identidades. MA dissertation, Linguística Aplicada, Brasília, DF, Brasil. 
Dixson, A. D., \& Rousseau. C. K. (2005). And we are still not saved: Critical race theory in education ten years later. Race ethnicity and education 8(1), 7-27.

Ferreira, A. J. (2004). Addressing 'race'/ethnicity in Brazilian Schools: A study of EFL teachers. PhD thesis. University of London, Institute of Education. London.

Ferreira, A. J. (2006). Formação de professores de língua inglesa e o prepara para o exercício do letramento crítico em sala de aula em prol das práticas sociais: um olhar acerca de raça/etnia. Línguas \& Letras 7(12), 171-187.

Ferreira, A. J. (2007). "What has race/ethnicity got to do with EFL teaching?” Linguagem \& Ensino 10(1), 211-233.

Ferreira, A. J.. (2008). Limites, desafios e possibilidades para aplicação de estratégias anti-racistas e da Lei Federal no 10.639/2003.” In A. J. Ferreira (Ed.). PEAB - Projeto de Estudos Afro-Brasileiros: Contexto, Pesquisas e Relatos de Experiências., (pp. 47-60). Cascavel: Unioeste.

Ferreira, A. J. (2011). Addressing Race/Ethnicity in Brazilian Schools: A Critical Race Theory Perspective. Seattle, WA, USA: CreateSpace.

Ferreira, A. J. (2012a). Identidades Sociais de Raça, Etnia, Gênero e Sexualidade: Práticas Pedagógicas em sala de aula de Línguas e Formação de Professores/as. Campinas: Pontes Editores.

Ferreira, A. J. (2012b). Identidades Sociais de Raça no Livro Didático de Inglês Mais Vendido no Brasil. In R. A. Harmuch, \& P. B. O. Saleh (Eds.). Identidade e Subjetividade: Configurações Contemporâneas, (pp. 99-114), Campinas: Mercado de Letras.

Ferreira, A. J. (2014). Teoria Racial Crítica e Letramento Racial Crítico: Narrativas e Contranarrativas de Identidade Racial de Professores de Línguas. Revista Da ABPN, 6 (14), 236-263.

Ferreira, A. J. (2015a). Letramento Racial Critico Através de Narrativas Autobiográficas: Com atividades Reflexivas. Ponta Grossa, Pr: Editora Estúdio Texto.

Ferreira, A. J. (2015b). (Org.). Narrativas Autobiográficas de Identidades Sociais de Raça, Gênero, Sexualidade e Classe em Estudos da Linguagem. Campinas, SP: Pontes Editores.

Ferreira, A. J. \& Ferreira, S. A. (2011). Raça/etnia, gênero e suas implicações na construção das identidades sociais em sala de aula de línguas. RevLet Revista Virtual de Letras, 3(2), 114-129.

Ferreira, A. J.. \& Camargo, M. (2014). O racismo cordial no livro didático de língua inglesa aprovado pelo PNLD. Revista da ABPN, 6(12), 177-202. 
Gillborn, D. (2009). Education policy as an act of white supremacy: Whiteness, critical race theory, and education reform. In E. Taylor, David G., and G. Ladson-Billings (Eds.), Foundations of critical race theory in education, (pp. 51-72). New York: Routledge.

Gomes, N. L. (2003). Educação, Identidade negra e formação de professores/as: um olhar sobre o corpo negro e o cabelo crespo. Educação e Pesquisa 29(1), 167-182.

Ibrahim, A., \& El Karim M. (1999). Becoming black: Rap and hip-hop, race, gender, identity, and the politics of ESL learning. Tesol Quarterly 33(3), 349-369.

Johnson Lachuk, A. S., \& Mosley, M.. (2012). Us \& Them? Entering a three-dimensional narrative inquiry space with white pre-service teachers to explore race, racism, and anti-racism. Race Ethnicity and Education 15(3), 311-330.

Jorge, M. L. S. (2012). Critical Literacy, Foreign Language Teaching and the Education about Race Relations in Brazil. The Latin Americanist 4, 79-90.

Kubota, R. (2002). (Un)Raveling Racism in a Nice Field Like TESOL. Tesol Quarterly 36(1), 84-92.

Kubota, R., \& Lin., A. (2006). Race and TESOL: Introduction to concepts and theories. Tesol Quarterly 40(3), 471-493.

Kubota, R., \& Lin. A. (2009). Race, Culture, and Identities in Second Language Education: Introduction to Research and Practice. In R. Kubota, \& A. Lin (Eds.). Race, culture and identities in second language education: Exploring critically engaged practice, (pp. 1-23). London: Routledge.

Kubota, R.. (2015). Race and language learning in multicultural Canada: towards critical antiracism. Journal of Multilingual and Multicultural Development, 36 (1), 1-10.

Ladson-Billings, G, \& Tate. W. F. (1995). Towards a Critical Race Theory of Education. Teachers College Record 97(1), 47-67.

Ladson-Billings, G. (1998). Just what is critical race theory and what's it doing in a nice field like education? Qualitative studies in Education 11(1), 7-24.

Leonardo, Z. (2002). The Souls of White Folk: Critical pedagogy, whiteness studies, and globalisation discourse. Race Ethnicity and Education 5(1), 29-50.

Liggett, T. (2014). The Mapping of a Framework: Critical Race Theory and TESOL. The Urban Review 46(1), 112-124. 
Luke, A. (2009). Race and Language as Capital in School: A Sociological template for language-education reform”. In R. Kubota, \& A. Lin.(Eds.) Race, culture and identities in second language education: Exploring critically engaged practice, (pp. 286-308). London: Routledge.

Marx, S, \& Pennington. J. (2003). Pedagogies of critical race theory: experimentations with white pre-service teachers. Qualitative studies in Education 16(1), 91-110.

Michael-Luna, S. (2009). Narratives in the Wild: Unpacking Critical Race Theory Methodology for Early Childhood Bilingual Education. In R. Kubota, \& A. Lin. Cculture and identities in second language education: Exploring critically engaged practice, (pp. 1-23). London: Routledge.

Milner, R. H. (2010). Race, narrative inquiry, and self-study in curriculum and teacher education. In R. H (Ed.) Milner Culture, curriculum, and identity in education, (pp. 181-206). New York: Palgrave Macmillan.

Milner, R. H. (2013). Counter-narrative as method: race, policy and research for teacher education,. Race Ethnicity and Education 16(3), 536-561.

Mitchell, K. (2013). Race, difference, meritocracy, and English: Majoritarian stories in the education of secondary multilingual learners. Race Ethnicity and Education, 16(3), 339-364.

Moita Lopes, L. P. (2002). Identidades Fragmentadas: A construção discursiva de raça, gênero e sexualidade em sala de aula. Campinas: SP: Mercado de Letras.

Motha, S. (2006). Racializing ESOL Teacher Identities in US K12 Public Schools. Tesol Quarterly 40(3), 495-518.

Norton, B. (2011). Researcher identity, narrative inquiry, and language teaching research. Tesol Quarterly 45(3), 415-439.

Paixão, M, J. P., Rossetto, I., Montovanele, F. \& Carvano, L. M. (2010). Relatório Anual Das Desigualdades Raciais No Brasil; 2009-2010. Laboratório De Análises Econômicas, Históricas, Sociais E Estatísticas Das Relações Raciais (Laeser). Rio de Janeiro: Garamond Editora.

Parker, L., \& Stovall. D. O. (2004). Actions Following Words: Critical race theory connects to critical pedagogy. Educational Philosophy and Theory 36(2), 167-182.

Pavlenko, A. (2007). Autobiographic narratives as data in applied linguistics. Applied Linguistics 28(2), 163-188.

Pennycook, A. (2001). Critical applied linguistics: a critical introduction. Mahwah, New Jersey and London: Lawrence Erlbaum Associates, Publishers LEA. 
Pennycook, A. (2010). Critical and alternative directions in applied linguistics. Australian Review of Applied Linguistics 33(2), 16.1-16.16.

Pessoa, R. R. 2014. A critical approach to the teaching of English: pedagogical and identity engagement. Revista Brasileira de Linguística Aplicada: 14(2), 353-372.

Romero, T. R. S, (Ed.). (2010). Autobiografias na (Re) Constituição de Identidades de Professores de Línguas: O Olhar Reflexivo. Campinas: Pontes Editores.

Ruecker, T. (2011). Challenging the native and non-native English speaker hierarchy in ELT: New directions from race theory. Critical Inquiry in Language Studies 8(4), 400-422.

Santos, J. S. (2011). Raça/Etnia, Cultura, Identidade e o Professor na aplicação da Lei no 10639/03 em aulas de língua inglesa: como? Mestrado Dissertação. Departamento de Ciências Humanas. Salvador, Universidade do Estado da Bahia, UNEB.

Silva, P. A. (2009). Reflexões Sobre Raça e Racismo em Sala de Aula: Uma Pesquisa com duas professoras de inglês negras. Faculdade de Letras Programa de Pós-Graduação em Letras e Linguística. Mestrado dissertação. Goiás, Universidade Federal de Goiás.

Telles, J. A. (2002). A trajetória narrativa: histórias sobre a prática pedagógica e a formação de professores de línguas. In T. Gimenez (Ed.). Trajetórias na formação de professores de línguas, (pp. 15-38). Londrina: Editora da Universidade Estadual de Londrina.

Tsui, A. B. M. (2007). Complexities of Identity Formation: A Narrative Inquiry of an EFL Teacher. Tesol Quarterly 41(4), 657-680.

van Dijk, T. A. (1993). Stories and Racism. In D, Mumby. Narrative and social control, (pp. 121-142). Newbury Park, CA: Sage. 